\title{
Electrophysiological, behavioural and biochemical effect of Ocimum basilicum oil and its constituents methyl chavicol and linalool on Musca domestica L.
}

\author{
Rajendran Senthoorraja ${ }^{1,2} \cdot K$ Kesavan Subaharan ${ }^{1}$ (D) - Sowmya Manjunath ${ }^{1}$. Vppalayam Shanmugam Pragadheesh ${ }^{3,5}$. \\ Nandagopal Bakthavatsalam ${ }^{1}$ • Muthu Gounder Mohan ${ }^{1}$. Sengottayan Senthil-Nathan ${ }^{4} \cdot$ Sekarappa Basavarajappa $^{2}$
}

Received: 11 January 2021 / Accepted: 30 April 2021 / Published online: 8 May 2021

(C) The Author(s), under exclusive licence to Springer-Verlag GmbH Germany, part of Springer Nature 2021

\begin{abstract}
Ocimum basilicum essential oil (EO) was evaluated for its biological effects on $M$. domestica. Characterization of $O$. basilicum EO revealed the presence of methyl chavicol (70.93\%), linalool (9.34\%), epi- $\alpha$-cadinol (3.69\%), methyl eugenol (2.48\%), $\gamma$ cadinene $(1.67 \%), 1,8$-cineole $(1.30 \%)$ and $(E)$ - $\beta$-ocimene $(1.11 \%)$. The basil EO and its constituents methyl chavicol and linalool elicited a neuronal response in female adults of $M$. domestica. Adult female flies showed reduced preference to food source laced with basil EO and methyl chavicol. Substrates treated with EO and methyl chavicol at $0.25 \%$ resulted in an oviposition deterrence of over $80 \%$. A large ovicidal effect was found for $O$. basilicum $\mathrm{EO}\left(\mathrm{EC}_{50} 9.74 \mathrm{mg} / \mathrm{dm}^{3}\right)$ followed by methyl chavicol $\left(E_{50} 10.67 \mathrm{mg} / \mathrm{dm}^{3}\right)$ and linalool $\left(E_{50} 13.57 \mathrm{mg} / \mathrm{dm}^{3}\right)$. Adults exposed to $E O\left(L_{50} 10.01 \mu \mathrm{g} /\right.$ adult $)$ were more susceptible to contact toxicity than to methyl chavicol and linalool $\left(\mathrm{LD}_{50} 13.62 \mu \mathrm{g} /\right.$ adult and $\mathrm{LD}_{50} 43.12 \mu \mathrm{g} /$ adult respectively). EO and its constituents methyl chavicol and linalool also induced the detoxifying enzymes Carboxyl esterase (Car E) and Glutathione S - transferases (GST).
\end{abstract}

Keywords Basil oil $\cdot$ Secondary metabolites $\cdot$ Housefly $\cdot$ Electrophysiology $\cdot$ Detoxifying enzymes $\cdot$ Ovipositional deterrence

Rajendran Senthoorraja and Kesavan Subaharan contributed equally to this work.

Responsible Editor: Philippe Garrigues

Kesavan Subaharan

Kesavan.Subaharan@icar.gov.in

1 Division of Germplasm Conservation and Utilization, ICAR - National Bureau of Agricultural Insect Resources, Bengaluru 560024, India

2 DOS in Zoology, University of Mysore, Mysore 570006, India

3 National Centre for Biological Sciences-TIFR, Bengaluru 560065, India

4 Division of Biopesticides and Environmental Toxicology, Sri Paramakalyani Centre for Excellence in Environmental Sciences, Manonmaniam Sundaranar University, Alwarkurichi, Tirunelveli, Tamil Nadu 627412, India

5 Present address: CSIR- Central Institute of Medicinal and Aromatic Plants, Regional Centre, Bengaluru 560065, India

\section{Introduction}

The cosmopolitan housefly, Musca domestica L. (Diptera: Muscidae), is synanotrophic and lives in close association with humans and livestock causing annoyance, food spoilage and pathogen transmission (causing enteric disease, typhoid, and shigellosis) (Sasaki et al. 2000; Kumar et al. 2012; Khamesipour et al. 2018; Moon 2019). The transmission of microbes is facilitated through fecal, body, and regurgitation routes (Fotedar 2001; Meerberg et al. 2007; Wanaratana et al. 2013). The ability of houseflies to acquire avian influenza H9N2 may aid in spreading spreading the virus to humans and poultry (Salamatian et al. 2020). Reports from Wuhan confirmed 2-10\% of COVID-19 patients had diarrhoea and abdominal pain, a symptom that could have occurred due to faecal-oral transmission (Wang et al. 2020). In such a situation, vectoral role of flies carrying virus from faecal visits to human settlements cannot be ruled out (Dehghani and Kassiri 2020).

$M$. domestica management in human settlements, animal and poultry sheds mainly involves the application of insecticides or raising the birds on feed premixed with growth 
regulators (Macovei et al. 2008; Ghosh and Zurek 2015). The excessive dependence on chemical insecticides leads to the development of insecticide resistance in flies to pyrethroids, organophosphates, spinosad, indoxacarb and spiromesifen (Khan et al. 2015; Alam et al. 2020) and also build-up of xenobiotics that are toxic to humans and nontarget animals. Alternatively, botanical-based insecticides pose minimal safety risks and can be used in tandem with biocontrol agents (Kaufman et al. 2010; Khan et al. 2015; Scott 2017; Saeed et al. 2018; Senthil-Nathan 2020; Shi et al. 2020). This necessitates the development of "green" insecticides and repellents with diverse modes of action (Pavela and Benelli 2016; Benelli and Pavela 2018; Pavela et al. 2019; Isman 2020) that can mitigate the problems posed by synthetic insecticides to humans and the environment (Isman 2017; Pandiyan et al. 2019; Ikbal and Pavela 2019). The essential oils (EO) are an alternative to synthetic insecticides as they possess potential biological effect on insect pests with low mammalian toxicity (Koul et al. 2008; Chellappandian et al. 2018; VasanthaSrinivasan et al. 2018). Several studies have exhibited the larvicidal, ovicidal, adulticidal, repellence, and ovipositional deterrence of essential oils on $M$. domestica which can be exploited for its management (Pavela and Benelli 2016; Khater and Geden 2019).

Sweet basil, Ocimum basilicum, belongs to the Lamiaceae family and is a herbaceous and perennial plant grown in Asia, Africa, Central and South America (Simon et al. 1999). $O$. basilicum EO is widely used in the preparation of food, cosmetics and medicine (da silva Moura et al. 2020). The major constituents of $O$. basilicum EO, methyl chavicol and linalool exhibit antioxidant, anesthetic, anti-inflammatory and antimicrobial properties (Radulovic et al. 2013; Varga et al. 2017). In addition, they are reported to be toxic (Rice and Coats 1994; Palacios et al. 2009; Tarelli et al. 2009; Gallardo et al. 2015; Tian 2017) and insect repellent (Delille 2007; Tian 2017).

The reports on basil EO and its constituents, linalool and methyl chavicol were limited to fumigant and contact toxicity to adults and larval stages of $M$. domestica (Palacios et al. 2009; Tian 2017). In our studies, we focused on the electrophysiological and olfactory response of $O$. basilicum EO and its major constituents to adult females of $M$. domestica. Furthermore, we investigated the ovicidal, adulticidal and the activity of detoxification enzyme in adult exposed to O. basilicum EO, linalool and methyl chavicol.

\section{Materials and methods}

\section{House fly rearing}

House fly, M. domestica adults were collected using a sweep net from suburbs of Bengaluru, India. The collected adult flies were kept in $30 \times 30 \times 30 \mathrm{~cm}$ cage (aluminium frame fitted with acrylic sheets). The flies were fed with diluted honey solution $(10 \%)$ in water. An oviposition substrate $(250 \mathrm{gm})$ prepared by mixing wheat bran + milk powder + egg yolk powder $(10$ : 2: 1) with water was placed in the cage to facilitate the mated flies to lay their eggs. The larvae on hatching continued to feed on wheat bran medium. When the larvae in the medium reached third instar, ragi (Elusine coracona) husk was added to the dry larval medium to facilitate pupation. The fly rearing unit was maintained at $28 \pm 2{ }^{\circ} \mathrm{C}$, RH $65 \pm 5 \%$. The bio stages (eggs $0-3 \mathrm{~h}$ old and 2-3 days old adult females) of the flies collected from the rearing chamber were used in experiments.

\section{Extraction and characterization of essential oil}

Leaves of $O$. basilicum $(300 \mathrm{~g})$ were extracted by hydrodistillation in a Clevenger type apparatus to obtain EO. The leaves along with $500 \mathrm{ml}$ of water were loaded into a round bottom flask placed over a heating mantle. The contents in the flask were heated to $100{ }^{\circ} \mathrm{C}$. The oil along with water collected in the receiver tube was phase separated using a separating funnel. The collected essential oil was dried by passing over anhydrous sodium sulphate to remove the moisture trace and stored in amber vials at $4{ }^{\circ} \mathrm{C}$ until use.

The $O$. basilicum oil was characterized using GC-MS (Agilent GC- 7890A (G3440A) and MS- G3171A 5975) as suggested by Ravindran et al. (2019). One $\mu l$ of $0.01 \%$ essential oil diluted in dichloromethane was introduced by microsyringe into injector port attached to HP-5 MS Phenylmethylsilox capillary column $(30 \mathrm{~m} \times 250 \mu \mathrm{m}$ i.d. $\times$ $0.25 \mu \mathrm{m}$ film thickness, Agilent Technologies, USA) through a glass liner. The oven and column temperature were maintained at $40{ }^{\circ} \mathrm{C}$ for $1 \mathrm{~min}$ and then raised at the rate of $20{ }^{\circ} \mathrm{C}$ per minute to $280^{\circ} \mathrm{C}$. The temperature during the post run was held at $300{ }^{\circ} \mathrm{C}$ for $10 \mathrm{~min}$. The temperature in injector and detector was maintained at $250{ }^{\circ} \mathrm{C}$. The total run was for 23 $\min$. In MS, the ion source temperature was set at $250^{\circ} \mathrm{C}$. The flow rate of the carrier gas Helium was maintained at $1 \mathrm{ml}$ per minute. An electron ionization (EI) mode with $70 \mathrm{eV}$ ionization energy was used for the GC-MS identification. Identification of the components in $\mathrm{EO}$ was done by considering the relative peak percent area, retention time and mass fragmentation pattern using the NIST library. Major constituents in oil were verified by co injecting the compounds.

\section{Chemicals}

Methyl chavicol and linalool used for bioassays were purchased from Sigma Aldrich. HPLC grade dichloromethane and acetone were purchased from Merck. Dimethyl-2,2dichlorovinyl phosphate (DDVP) and Imidacloprid (PESTANAL ${ }^{\circledR}$ ) analytical standard were purchased from Sigma Aldrich. Eserine and Fast Blue RR salt were procured 
from Fluka (Sigma Aldrich). $\alpha$-Napthyl acetate ( $\alpha$-NA), 2,4dinitrochlorobenzene (CDNB), Coomassie brilliant blue G-250, pyrogallol, guaiacol, and $\mathrm{H}_{2} \mathrm{O}_{2}$ were purchased from Shanghai Chemical Industry Co., Ltd, China.

\section{Electroantennography (EAG)}

The response of $M$. domestica adult female antennae (3 days old) to sweet basil EO, methyl chavicol, linalool and neem oil was recorded using an electroantennographic system (Syntech). The dual electrode probe was used for mounting the antennal prep. The head of the adult female fly was decapitated and mounted on one electrode and the proximal tip funiculus to another electrode using a conductive gel (Spectra 360 Parker, Orange, New Jersey). The clean air (activated charcoal filtered) was continuously flushed over the antennae. The EO and its constituent's methyl chavicol, linalool and neem oil were diluted in HPLC grade dicholoromethane at concentration of $1 \mu \mathrm{g} \mu \mathrm{L}^{-1}$. Dichloromethane alone was used as a control. One $\mu \mathrm{l}$ of the aliquot amounting to $1 \mu \mathrm{g}$ of the test compound placed on Whatman filter paper strips (Advantec 5C $(110 \mathrm{~mm})$ Japan of $2 \mathrm{~cm}$ length and $4 \mathrm{~mm}$ diameter) was dried for $5 \mathrm{~min}$ in fume hood, and then it was inserted into the Pasteur pipettes. This setup was connected to stimulus controller (CS 05 Syntech) by Tygon silicone tube. The first puff was blown off after 30 seconds of loading filter paper. After sixty seconds, the antennae were exposed to vapour phase of the stimulus through pipette placed $15 \mathrm{~mm}$ upstream from the antennae that had continuous air stream (pulse time 0.5 seconds, continuous flow $25 \mathrm{ml} / \mathrm{s}$, pulse flow $21 \mathrm{ml} / \mathrm{s}$ ) as suggested by Venugopal and Subaharan (2019). Between the stimulus puffs, a time delay of $20 \mathrm{~s}$ was maintained. The antennal responses were recorded through a high impedance probe that was in turn connected to amplifier (IDAC-4, Syntech), and the signals were recorded with EAG software (Syntech). Responses were expressed as a summated response of neurons, sorted according to shape and amplitude, emitted during $1 \mathrm{~s}$ after the onset of the stimulation. The control stimulus was at the beginning, middle and end of each session. EO and its constituents and neem oil were tested on six fly antennae with four replications of per stimuli per antennae in randomized manner.

\section{Y olfactometer assay}

The olfactory response of 2-3 days old adult females to sweet basil EO its constituent methyl chavicol, linalool and neem oil was evaluated using a glass Y-tube olfactometer having a main arm of $17 \mathrm{~cm}$ and choice arms of $17 \mathrm{~cm}$ with an inner diameter of $4 \mathrm{~cm}$. Atmospheric air pumped using an air sampler was allowed to flow out through activated charcoal cartridge with a flow rate of $0.5 \mathrm{~L} / \mathrm{min}$. The purified air was then let into the arms of the Y-tube with steady flow rate. Whatman No. 1 filter paper stripes ( $3 \mathrm{~cm}$ length and $0.5 \mathrm{~cm}$ width) were treated with $200 \mu \mathrm{L}$ of $20 \%$ sugar solution and dried for 30 min. To this $10 \mu \mathrm{L}$ of $100 \mathrm{ppm}$ of odorants diluted in dichloromethane was loaded, and the paper strips were allowed to dry in room temperature for $10 \mathrm{~min}$ to permit the solvent to evaporate. The paper strips prepared as mentioned above without the odorants was used as control. Both treated and control paper strips were inserted into an odour tube that was connected between the air flow tube and the Y-tube arm. The entire Y-tube setup was placed inclined at $20^{\circ}$. Pairwise comparison was made between odorants and control. The adult female flies were starved for $4 \mathrm{~h}$ with water satiation prior to test. A total of 100 female flies $(N=100)$ were introduced into the main arm. The choice made by the flies in an arm was considered if they crossed the halfway mark made in the arm in 3 min of start of the test. Those flies that failed to participate in the test were considered non-respondents. The odorants were switched between the arms to avoid position effect. The test was conducted at room temperature of $25 \pm 2$ ${ }^{\circ} \mathrm{C}$ under red light with slight modification as suggested by Ravindran et al. (2019).

\section{Oviposition repellence}

Gravid M. domestica females (10 Nos.) housed in cage ( $30 \times$ $30 \times 30 \mathrm{~cm}$ ) made of aluminium frame having acrylic sheets were exposed to $2 \mathrm{~g}$ of oviposition substrate (wheat bran + milk powder + egg yolk powder (10:2:1) treated with EO, methyl chavicol, linalool and neem oil dissolved in acetone so as to achieve $0.05,0.15$ and $0.25 \%$ concentrations. Oviposition substrate treated with acetone alone was maintained as control. In both the cases, the solvent was allowed to evaporate from the oviposition substrate prior to their placement in treated and control dish that were placed at diagonal ends in the floor of the cage. Four replications were maintained (One cage per replicate). The number of eggs laid were counted after $24 \mathrm{~h}$. The percent effective repellency (ER\%) and Oviposition Activity Index (OAI) for flies exposed to EO, linalool, methyl chavicol and neem oil were calculated.

\section{Ovicidal effect}

Freshly laid $M$. domestica eggs ( $0-3 \mathrm{~h})$ were collected using a soft paint brush. Twenty eggs of $M$. domestica were placed in the base of the 50-ml plastic sample container (Tarsons) having screw cap lid. Sweet basil EO, methyl chavicol and linalool of varied concentration ranging from 0.5 to $79 \mathrm{mg} / \mathrm{dm}^{3}$ were applied to filter paper attached to the base of the lid. Acetone alone was maintained as control and DDVP was maintained as positive control. This setup was sealed tightly using a parafilm and placed in incubator at $28 \pm 2{ }^{\circ} \mathrm{C}$ and $\mathrm{RH}$ $65 \pm 5 \%$. The number of hatched and unhatched eggs were counted after $48 \mathrm{~h}$. The experiments were replicated for five times. 


\section{Contact toxicity}

Topical bioassay

Acute toxicity of EO, methyl chavicol and linalool to female M. domestica was assessed by topical application. Acetone was used as a solvent to prepare varying concentration of EO, methyl chavicol and linalool. Acetone alone was maintained as negative control and imidacloprid was used as positive control. Preliminary range finding test was done to fix the doses. Two-day-old adult female flies were immobilized using $\mathrm{CO}_{2}$. The flies were transferred to flat surface, and $1 \mu \mathrm{l}$ of the test compounds were placed on the pronota using a microapplicator. The treated adults were transferred to an insect breeding dish (Himedia) having ventilation in the lid. The adults had access to $10 \%$ honey solution soaked in absorbent cotton. Four replications were maintained per treatment. Mortality was assessed $24 \mathrm{~h}$ after the treatment. Those flies that ceased to move its appendages in mild pin prick were considered dead (Subaharan et al. 2021).

\section{Enzyme assays}

The surviving flies after treatment with $\mathrm{LC}_{50}$ doses of $\mathrm{EO}$, methyl chavicol and linalool $(9,98,13.62$ and $43.13 \mu \mathrm{g} / \mathrm{adult}$, respectively) were used for the extraction of whole-body homogenate. Acetone-treated adults were used as control. The flies were homogenised in ice cold $50-\mathrm{mM}$ phosphate buffer (pH 7.4). Homogenates were centrifuged at $4{ }^{\circ} \mathrm{C}$ for $20 \mathrm{~min}$ at $10,000 \mathrm{rpm}$. The supernatant was subjected to protein estimation using Bradford's method (Bradford 1976) and used as an enzyme source for the estimation of carboxylesterase (CarE) and glutathione S-transferase (GST) activities.

Glutathione S-transferase (GST) activity was determined as described by Habig et al. (1974) and Zhang et al. (2007). The components in reaction mixture include $30 \mu \mathrm{l}$ of enzyme solution, $10 \mu \mathrm{l}$ each of reduced glutathione (GSH) and 1chloro-2,4-dinitrobenzene (CDNB) (dissolved in ethanol and prepared with $50 \mathrm{mM}$ po4 buffer, $\mathrm{PH} 7.4$ ) and $950 \mu \mathrm{l}$ phosphate buffer. Control mixture had $10 \mu \mathrm{l}$ each of GSH and1chloro-2,4-dinitrobenzene and 950 or $980 \mu$ of phosphate buffer. The rate of change in absorbance at $340 \mathrm{~nm}$ was measured for $5 \mathrm{~min}$ in 96-well microplate reader and converted to specific activity using extinction coefficient of $9.6 \mathrm{mM}^{-1}$ after necessary path length correction.

The activity of carboxylesterases (Car E) was determined using the method suggested by Li et al. (2007). The reaction mixture consisting of $15 \mu \mathrm{l}$ of enzyme homogenate made up to 500 ul with sodium phosphate buffer (50 mM, pH 7.4) and $800 \mu \mathrm{l} \alpha$ - naphthyl acetate (dissolved in acetone, prepared in $\mathrm{PO}_{4}$ buffer) was incubated in dark condition for $20 \mathrm{~min}$. The control mix had $800 \mu \mathrm{l}$ of substrate and $500 \mu \mathrm{l}$ of phosphate buffer $(50 \mathrm{mM}, \mathrm{pH}$
7.4). Formation of blue colour on addition of $200 \mu \mathrm{l}$ of staining solution indicated the production of $\alpha$-napthol. The absorbance was measured at $595 \mathrm{~nm}$ using microplate reader (iMark, BioRad). Enzyme activity in the sample was calibrated using $\alpha$-napthol standard curve.

For both the enzyme estimation, three biological replicates were maintained per treatment. The specific activity of the enzyme was expressed as $\mathrm{nmol} / \mathrm{min} / \mathrm{mg}$ protein.

\section{Statistical analysis}

The egg and adult mortality data were subjected to probit analysis to determine median lethal dose $\mathrm{LD}_{50}$ and the corresponding $95 \%$ CI values and chi-square test were calculated. In the case of Y-tube olfactory assay, the binomial test was used to compare the orientation of the flies to the arms with odorant and control. Pooled EAG response of antennae to EO and its constituents, variations in effective repellence (ER), $\mathrm{OAI}$ and variation in enzyme activity was compared using one-way analysis of variance (ANOVA) followed by Tukey's Post hoc test $(P<0.05)$ using SPSS.

Oviposition Activity Index (OAI) was calculated using the formula.

$\mathrm{OAI}=(\mathrm{NT}-\mathrm{NC}) /(\mathrm{NT}+\mathrm{NC})$

where NT is the total number of eggs on the treated substrate and $\mathrm{NC}$ the total number of eggs on the control substrate (Cheah et al. 2013). For OAI values $\leq-0.3$, the EO was considered as repellent (Kramer and Mulla 1979).

The percent effective repellency (ER\%) for EO, linalool, methyl chavicol and neem oil was calculated using the following formula:

$\mathrm{ER} \%=\mathrm{NC}-\mathrm{NT} / \mathrm{NC} \times 100$ as suggested by Siriporn and Mayura (2012)

\section{Results}

\section{GC-MS analysis for Ocimum basilicum EO}

The hydrodistillation of $O$. basilicum yielded an essential oil content of $0.5 \mathrm{ml} / 100 \mathrm{~g}$ of herbage. The extracted O. basilicum EO was characterized by gas chromatography coupled to mass spectroscopy. The compounds were identified by the reported retention index. The chemical formula, molecular weight, and their chemical structures are presented in Table 1 and Fig, 1. The major components present in $O$. basilicum EO were methyl chavicol $(70.93 \%)$, linalool $(9.34 \%)$, epi- $\alpha$-cadinol (3.69\%), methyl eugenol $(2.48 \%), \gamma$-cadinene $(1.67 \%), 1,8$-cineole $(1.30 \%)$ and $(E)-\beta$-ocimene $(1.11 \%)$. 
Table 1 Chemical composition of the $O$. basilicum essential oil

\begin{tabular}{|c|c|c|c|c|c|c|}
\hline No & Component & Chemical formulae & $\begin{array}{l}\text { Molecular weight } \\
\mathrm{g} / \mathrm{mol}\end{array}$ & Reported RRI & Experimental RRI & $\begin{array}{l}\text { Percentage } \\
\text { Composition }\end{array}$ \\
\hline 1 & $\beta$-Pinene & $\mathrm{C}_{10} \mathrm{H}_{16}$ & 136 & 974 & 978 & 0.12 \\
\hline 2 & Myrcene & $\mathrm{C}_{10} \mathrm{H}_{16}$ & 136 & 988 & 991 & 0.48 \\
\hline 3 & Limonene & $\mathrm{C}_{10} \mathrm{H}_{16}$ & 136 & 1024 & 1028 & 0.14 \\
\hline 4 & 1,8-Cineole & $\mathrm{C}_{10} \mathrm{H}_{18} \mathrm{O}$ & 154 & 1026 & 1032 & 1.3 \\
\hline 5 & (E)- $\beta$-ocimene & $\mathrm{C}_{10} \mathrm{H}_{16}$ & 136 & 1044 & 1047 & 1.11 \\
\hline 6 & Linalool & $\mathrm{C}_{10} \mathrm{H}_{18} \mathrm{O}$ & 154 & 1095 & 1101 & 9.34 \\
\hline 7 & Camphor & $\mathrm{C}_{10} \mathrm{H}_{16} \mathrm{O}$ & 152 & 1141 & 1140 & 1.44 \\
\hline 8 & Methyl chavicol & $\mathrm{C}_{10} \mathrm{H}_{12} \mathrm{O}$ & 148 & 1195 & 1208 & 70.93 \\
\hline 9 & $p$-Anisaldehyde & $\mathrm{C}_{8} \mathrm{H}_{8} \mathrm{O}_{2}$ & 137 & 1247 & 1257 & 0.28 \\
\hline 10 & Bornyl acetate & $\mathrm{C}_{12} \mathrm{H}_{20} \mathrm{O}_{2}$ & 196 & 1287 & 1288 & 0.1 \\
\hline 11 & $\beta$-Bourbonene & $\mathrm{C}_{15} \mathrm{H}_{24}$ & 204 & 1387 & 1387 & 0.09 \\
\hline 12 & $\beta$-Elemene & $\mathrm{C}_{15} \mathrm{H}_{24}$ & 204 & 1389 & 1394 & 0.62 \\
\hline 13 & Methyl eugenol & $\mathrm{C}_{11} \mathrm{H}_{14} \mathrm{O}_{2}$ & 178 & 1403 & 1408 & 2.48 \\
\hline 14 & $\beta$-Caryophyllene & $\mathrm{C}_{15} \mathrm{H}_{24}$ & 204 & 1417 & 1422 & 0.45 \\
\hline 15 & $\alpha$-Guaiene & $\mathrm{C}_{15} \mathrm{H}_{24}$ & 204 & 1437 & 1441 & 0.29 \\
\hline 16 & $\alpha$-Humulene & $\mathrm{C}_{15} \mathrm{H}_{24}$ & 204 & 1452 & 1456 & 0.24 \\
\hline 17 & Germacrene D & $\mathrm{C}_{15} \mathrm{H}_{24}$ & 204 & 1484 & 1484 & 0.16 \\
\hline 18 & Bicyclogermacrene & $\mathrm{C}_{15} \mathrm{H}_{24}$ & 204 & 1500 & 1499 & 0.35 \\
\hline 19 & $\alpha$-Bulnesene & $\mathrm{C}_{15} \mathrm{H}_{24}$ & 204 & 1509 & 1508 & 0.63 \\
\hline 20 & $\gamma$-Cadinene & $\mathrm{C}_{15} \mathrm{H}_{24}$ & 204 & 1513 & 1517 & 1.67 \\
\hline 21 & trans-Calamenene & $\mathrm{C}_{15} \mathrm{H}_{22}$ & 202 & 1521 & 1526 & 0.12 \\
\hline 22 & (E)-Nerolidol & $\mathrm{C}_{15} \mathrm{H}_{26} \mathrm{O}$ & 222 & 1561 & 1566 & 0.11 \\
\hline 23 & 4-Methoxycinnamaldehyde & $\mathrm{C}_{10} \mathrm{H}_{10} \mathrm{O}_{2}$ & 162 & 1562 & 1571 & 0.67 \\
\hline 24 & Spathulenol & $\mathrm{C}_{15} \mathrm{H}_{24} \mathrm{O}$ & 220 & 1577 & 1582 & 0.91 \\
\hline 25 & Caryophyllene oxide & $\mathrm{C}_{15} \mathrm{H}_{24} \mathrm{O}$ & 220 & 1582 & 1587 & 0.5 \\
\hline 26 & Humulene epoxide II & $\mathrm{C}_{15} \mathrm{H}_{24} \mathrm{O}$ & 220 & 1608 & 1613 & 0.25 \\
\hline 27 & 1,10-di-epi-Cubenol & $\mathrm{C}_{15} \mathrm{H}_{26} \mathrm{O}$ & 222 & 1618 & 1619 & 0.54 \\
\hline 28 & Epi- $\alpha$-cadinol & $\mathrm{C}_{15} \mathrm{H}_{26} \mathrm{O}$ & 222 & 1638 & 1646 & 3.69 \\
\hline 29 & $\alpha$-Eudesmol & $\mathrm{C}_{15} \mathrm{H}_{26} \mathrm{O}$ & 222 & 1652 & 1655 & 0.12 \\
\hline \multirow[t]{2}{*}{30} & $\alpha$-Cadinol & $\mathrm{C}_{15} \mathrm{H}_{26} \mathrm{O}$ & 222 & 1652 & 1659 & 0.18 \\
\hline & Total & & & & & 99.31 \\
\hline
\end{tabular}

\section{Electroantennograph (EAG) response}

The sweet basil EO and its constituents methyl chavicol, linalool and positive control neem oil at $1 \mu \mathrm{g}$ treatment caused the neuronal response in female adults (Fig. 2) $(t=2.71 ; P<$ $0.05)$. The mean EAG response to air was less than $0.5 \mathrm{mV}$. Sweet basil EO and its major constituent methyl chavicol caused highest mean antennal response of 2.51 and $2.38 \mathrm{mV}$, respectively, and were at par. The response of female adults to linalool $(1.69 \mathrm{mV})$ was lower than the methyl chavicol but higher than neem oil $(1.37 \mathrm{mV})$.

\section{Olfactometer bioassay}

There was significant reduction in adult female flies selecting the arm having food source with sweet basil EO $(P<0.05)$ and methyl chavicol $(P<0.05)$ as compared with arm having food source alone (Control). However, there was no significant difference between the flies choosing the arms having food source with linalool $(P=0.22)$ and neem oil $(\mathrm{P}=0.7)$ and control having food source alone (Fig. 3).

\section{Ovipositional repellence}

Effective repellence (ER\%) and oviposition activity index (OAI) of $O$. basilicum EO and its constituent's methyl chavicol and linalool at three concentration $(0.05,0.15$ and $0.25 \%$ ) was determined. The ER\% and OAI for EO and its constituents was concentration dependant and increased with concentration. Among the samples tested, higher oviposition deterrence to $M$. domestica adults was observed in $\mathrm{EO}$ $(89.52 \pm 1.00)$, methyl chavicol $(80.12 \pm 2.40)$ and linalool $(78.99+2.93)$ at a dose of $0.25 \%$ which was superior to neem oil $0.25 \%$. EO and methyl chavicol at $0.15 \%$ were at par in causing oviposition deterrence to $M$. domestica adults. At a lower concentration of $0.05 \%$ the EO, methyl chavicol and linalool caused a lowest deterrence ranging from 27.83 $35.86 \%\left(\mathrm{~F}_{11,36}=50.07 \mathrm{P}<0.001\right)$. Across the concentration, neem oil caused lower oviposition deterrence.

$O$. basilicum EO, methyl chavicol, linalool and neem oil caused significant difference on OAI. O. basilicum EO, methyl chavicol at $0.25 \%$ caused an $\mathrm{OAI}-0.81 \pm 0.01$ and $-0.67 \pm$ 0.03 , respectively. All the samples tested at 0.15 and $0.05 \%$ recorded OAI value below -0.5 . An OAI value from -0.5 to -1 is an indication of good ovipositional repellence effect. In 


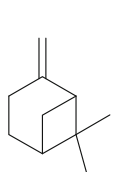<smiles>C=CC(=C)CCC(C)C</smiles><smiles>C=C(C)C1CC=C(C)CC1</smiles><smiles>CC12CCC(C1)C1CCC(C)(O2)C1(C)C</smiles><smiles>C=CC(C)=CCC=C(C)C</smiles><smiles>C=CC(C)(O)CCC=C(C)C</smiles>

$\beta$-Pinene

Myrcene

Limonene

1,8-Cineole

(E)- $\beta$-Ocimene

Linalool<smiles>CC12CCC(CC1=O)C2(C)C</smiles><smiles>C=CCc1ccc(OC)cc1</smiles><smiles>COc1ccc(C(C)=O)cc1</smiles><smiles>CC(=O)OC1CC2(C)CCC1(C)C2(C)C</smiles><smiles>C=CC1(C)CCC(C(=C)C)CC1C(=C)C</smiles>

Camphor

Methyl

p-Anisaldehyde

Bornyl

$\beta$-Bourbonene

$\beta$-Elemene

Chavicol

acetate<smiles>C=CCc1ccc(OC)c(OC)c1</smiles><smiles>C=C1CC/C=C(/C)CCC2C1CC2(C)C</smiles><smiles>C=C(C)C1CCC(C)C2=C(C1)C(C)CC2</smiles><smiles>CC1=CCC(C)(C)CCC(C)=CCC1</smiles><smiles>C=C1C=CC(C(C)C)CCC(C)=CCC1</smiles>

Methyl

$\beta$-Caryophyllene

$\alpha$-Guaiene

$\alpha$-Humulene

Germacrene D

eugenol<smiles>CC1=CCCCC2C(C)C2C1C</smiles>

Bicyclogermacrene

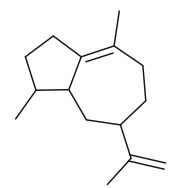

$\alpha$-Bulnesene<smiles>C=C1CCC(C(C)C)C2C=C(C)CCC12</smiles>

$\gamma$-Cadinene

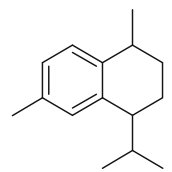

trans-Calamenene<smiles>C=CC(C)(O)CCC=C(C)CCC=C(C)C</smiles><smiles>COc1ccc(/C=C/C(C)=O)cc1</smiles><smiles>C=C1CCC2C(C3C(C)(C)CCC23C)C1(C)C</smiles><smiles>C=C1CCCC2OC2(C)CCC2C(CC2(C)C)C1C</smiles><smiles>CC(=CCC(C)(C)C)CCC1OC1(C)CCCC(C)(C)C</smiles>

(E)-Nerolidol

$$
\text { 4-Methoxy }
$$

$$
\text { Caryophyllene }
$$

Humulene cinnmaldehyde

oxide<smiles>CC1=CC2C(C(C)C)CCC(C)C2(O)CC1</smiles>

1,10-di-epi

-Cubenol<smiles>CC1=C[C@]23CCC(C(C)C)[C@@H]2CC[C@H](O)[C@H]3C1</smiles>

Epi-a-cadinol<smiles>CC1=CCCC2(C)CCC(C(C)(C)O)CC12</smiles>

$\alpha$-Eudesmol<smiles>CC1=C[C@H]2CCC[C@](C)(O)[C@@]2(C)CC1C(C)C</smiles>

$\alpha$-Cadinol

Fig. 1 Structures of chemical constituents in O. basilicum essential oil 
Fig. 2. Mean (+ SE) antennal EAG responses of female $M$. domestica to the assay performed using $1 \mu \mathrm{L}$ of $1000 \mathrm{ppm}$ of sweet basil EO, methyl chavicol, linalool and neem oil. Bars having same letter do not differ significantly at $P<$ 0.05 (ANOVA followed by Tukey test)

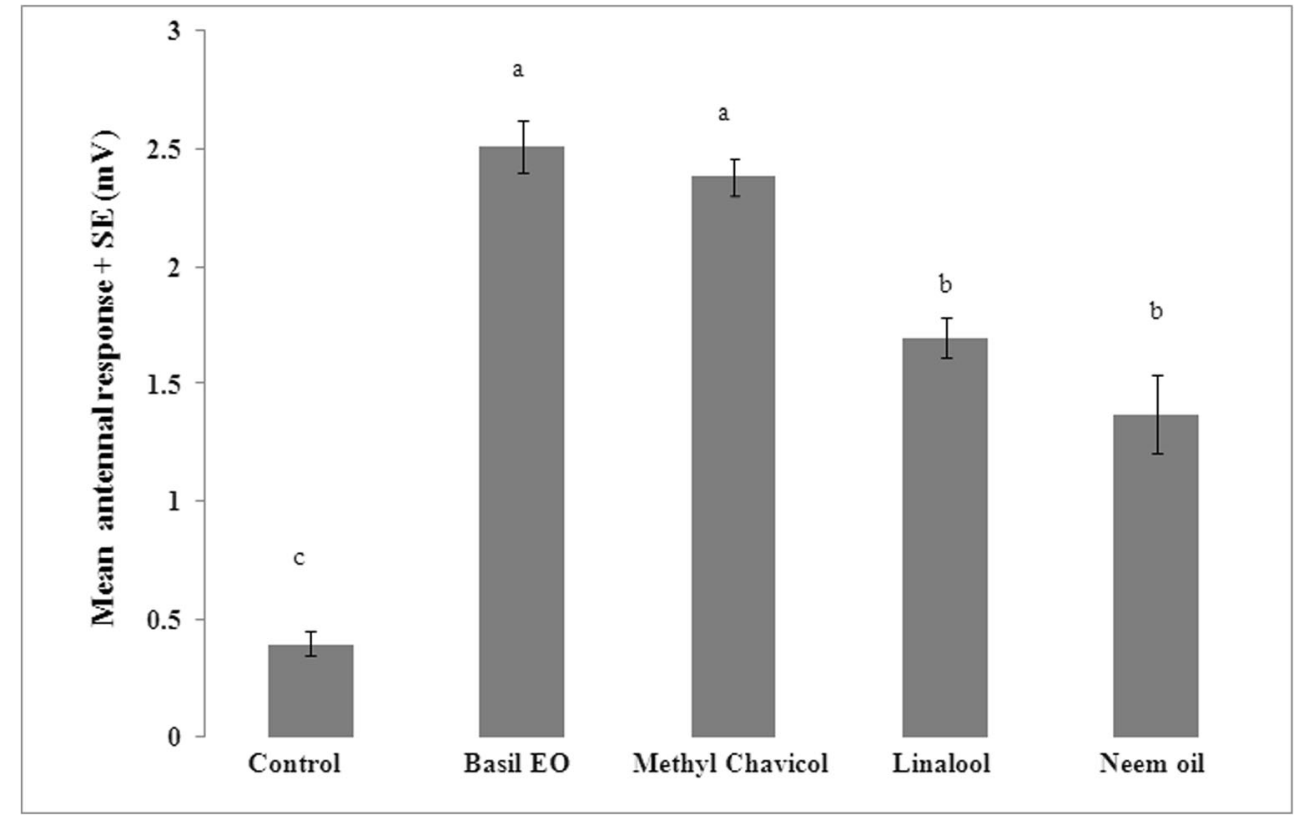

the case of neem oil, all the doses tested had OAI less than $-0.5\left(\mathrm{~F}_{11,36}=53.87 P<0.001\right)($ Table 2$)$.

\section{Ovicidal effect}

O. basilicum EO and its constituent methyl chavicol and linalool were evaluated for ovicidal activity. O. basilicum EO had 5.8-fold higher ovicidal activity $\left(\mathrm{EC}_{50} 9.74 \mathrm{mg} / \mathrm{dm}^{3}\right)$ on M. domestica eggs than linalool $\left(\mathrm{EC}_{50} 13.57 \mathrm{mg} / \mathrm{dm}^{3}\right)$. Among the constituents, methyl chavicol elicited 1.27-fold higher toxicity than linalool $\left(\mathrm{EC}_{50} 10.67 \mathrm{mg} / \mathrm{dm}^{3}\right)$. The ovicidal activity of DDVP was superior to $\left(\mathrm{EC}_{50} 390.37 \mathrm{mg} / \mathrm{dm}^{3}\right)$ EO and its constituents (Table 3).

\section{Topical bioassay}

A toxicity assay carried out showed that $O$. basilicum EO topical application resulted in higher mortality over methyl chavicol and linalool to adult stages. Adults exposed to EO $\left(\mathrm{LD}_{50} 10.01 \mu \mathrm{g} /\right.$ adult $)$ were more susceptible than those exposed to methyl chavicol and linalool ( $\mathrm{LD}_{50} 13.62 \mu \mathrm{g} /$ adult and $\mathrm{LD}_{50} 43.12 \mu \mathrm{g} /$ adult, respectively). Imidacloprid was more toxic $(1.41 \mu \mathrm{g} /$ adult $)$ than EO and its constituents (Table 4).

\section{Enzyme assay}

The effect $\mathrm{LD}_{50}$ dose of $O$. basilicum $\mathrm{EO}$, methyl chavicol and linalool on $M$. domestica adult detoxifying enzymes carboxyl esterase and GST is reported in the Table 5 .

Adults exposed to linalool at $\mathrm{LD}_{50}$ value exhibited inhibition of GST, but it was on par with control. However, LD $_{50}$ values of EO and methyl chavicol caused induction of GST levels with EO having a higher ER (4.61) than methyl chavicol (3.09) $\left(\mathrm{F}_{6,14}=224.49 P<.005\right)$. Topical application of EO, methyl chavicol and linalool induced the enzymes Car $E$ in adults. In the case of Car $E$ levels in adults, those exposed to methyl chavicol at $\mathrm{LD}_{50}$ had $\mathrm{Car} E$ levels at par with control samples. Linalool had higher level of induction of Car E in adults than $O$. basilicum EO $\left(\mathrm{F}_{6,14}=224.49 P<.005\right)$.

\section{Discussion}

Indiscriminate use of chemicals has led to development of insecticide resistance and negative effects to consumers. There is a growing demand for environmentally safe pesticides to manage $M$. domestica. Essential oils (EO) derived from plant parts contain bioactive compounds that can be used in isolation or in combination for managing pests of agriculture, medical and veterinary importance (Isman 2006; Pavela 2011; Pavela and Benelli 2016; Senthil-Nathan 2020; Khater and Geden 2019). The biodegradable nature and safety of these botanically-derived chemicals to nontarget organisms provides an alternative to synthetic insecticides (Poorjavad et al. 2014; Chellappandian et al. 2019). The potency of essential oil and its constituents against M. domestica has been reported earlier (Sinthusiri and Soonwera 2014; Benelli et al. 2018). The insecticidal, ovicidal, deterrence/repellence and growth regulating effect of $O$. basilicum crude extracts and EO against M. domestica was reported earlier (Pavela 2008a; El Zayyat et al. 2015; Chowdhary et al. 2018). 


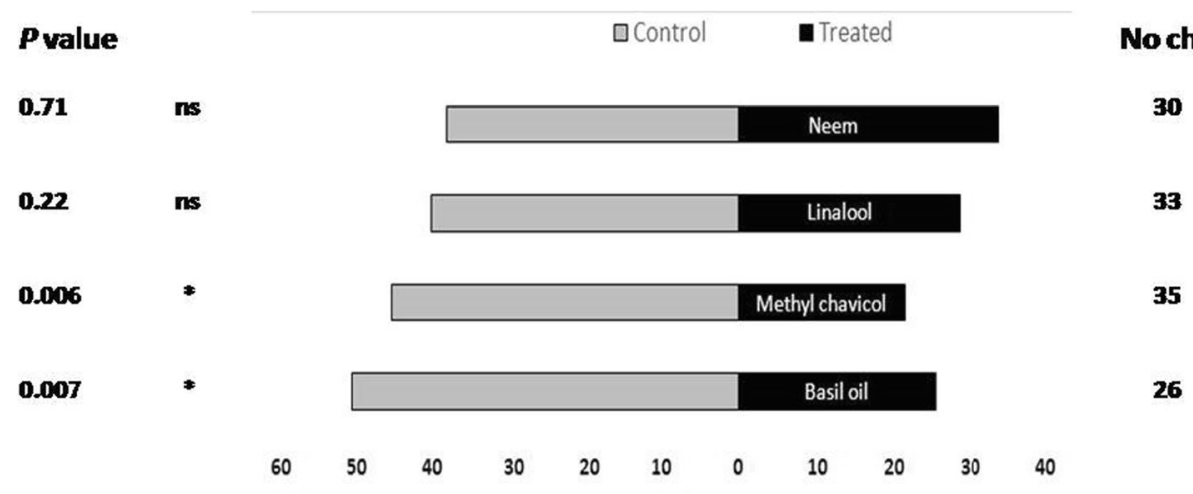

Fig. 3 Behavioural response of adult female $M$. domestica in a two choice Y- olfactometer (Per cent repelled $n=100$ ). Starved adult female flies were offered a choice between treated arm (Food source with sweet basil EO and its constituents' methyl chavicol, linalool and neem oil) and control arm (Food source alone). Both bars represent the per cent flies

\section{Chemical characterization}

In our study, sweet basil EO contained methyl chavicol (70.93 $\%)$ and linalool $(9.34 \%)$ as major constituents. This agrees with earlier reports mentioning methyl chavicol, linalool, $\beta$ elemene and camphor as major constituents of basil oil (Sonmezdag et al. 2018). The proportion of the constituents in basil oil varies according to the plant chemotype (Telci et al. 2006; Ogendo et al. 2008), such as methyl chavicol, linalool, methyl eugenol and methyl cinnamate types (Lawrence 1998). The EO of $O$. basilicum in our study contained thirty components, accounting for $99.31 \%$ of the total composition. As the EO used in our study had a higher load of methyl chavicol (70.93\%), it could be considered a methyl chavicol chemotype as proposed by Varga et al. (2017).

\section{\% Attraction}

orienting to treated and control arm. The non-responding adult female flies were presented in right hand side (No choice \%). Asterisks show a preference that was significantly different (binomial test) from a 50:50 distribution: $*=P<0.05$. The flies that failed to respond were excluded from the statistical analysis

In our study, the EAG assay revealed that the neuronal response of the antennae of adult female $M$. domestica was higher to sweet basil EO and methyl chavicol followed by linalool and neem oil. As EAG response is linked to insect olfaction (Ghabbari et al. 2018) higher amplitude of response trace to EO and methyl chavicol may be due to higher number of receptors in antennal neuron to these stimuli that may influence the fly's behaviour. Basil oil when presented at $100 \mathrm{ng}$ produced a mean antennal response of $0.99 \mathrm{mv}$ in the coconut rhinoceros beetle, Oryctes rhinoceros (Ravindran et al. 2019). White and Hobson (1993) reported that methyl chavicol elicited an EAG response in the mountain pine beetle. Methyl chavicol was reported as a antiaggregant to bark beetles. When methyl chavicol was mixed with attractive bait, it reduced the attraction of Western pine beetle, Dendroctonus

Table 2 Effective repellence of O. basilicum EO, methyl chavicol, linalool and neem oil against $M$. domestica

\begin{tabular}{llll}
\hline Test sample & Concentration $(\%)$ & Effective Repellency (ER) & OAI \\
\hline O. basilicum EO & 0.05 & $35.86 \pm 0.88^{\mathrm{e}}$ & $-0.21 \pm 0^{\mathrm{d}}$ \\
& 0.15 & $71.44 \pm 4.24^{\mathrm{bc}}$ & $-0.50 \pm .02^{\mathrm{c}}$ \\
& 0.25 & $89.52 \pm 1.00^{\mathrm{a}}$ & $-0.81 \pm 0.01^{\mathrm{a}}$ \\
Methyl chavicol & 0.05 & $33.27 \pm 0.95^{\mathrm{e}}$ & $-0.19 \pm 0.0^{\mathrm{d}}$ \\
& 0.15 & $59.81 \pm 4.36^{\mathrm{cd}}$ & $-0.43 \pm 0.04^{\mathrm{c}}$ \\
& 0.25 & $80.12 \pm 2.40^{\mathrm{ab}}$ & $-0.67 \pm 0.03^{\mathrm{ab}}$ \\
Linalool & 0.05 & $31.28 \pm 2.07^{\mathrm{e}}$ & $-0.18 \pm 0.01^{\mathrm{d}}$ \\
& 0.15 & $56.54 \pm 3.75^{\mathrm{d}}$ & $-0.39 \pm 0.03^{\mathrm{c}}$ \\
& 0.25 & $78.99 \pm 2.93^{\mathrm{ab}}$ & $-0.65 \pm 0.03^{\mathrm{b}}$ \\
Neem oil & 0.05 & $27.83 \pm 3.57^{\mathrm{e}}$ & $-0.16 \pm 0.02^{\mathrm{d}}$ \\
& 0.15 & $53.95 \pm 1.70^{\mathrm{d}}$ & $-0.37 \pm 0.01^{\mathrm{c}}$ \\
& 0.25 & $62.31 \pm 4.18^{\mathrm{cd}}$ & $-0.45 \pm 0.04^{\mathrm{c}}$ \\
\hline
\end{tabular}

The data are given as Mean $\pm \mathrm{SE}$. *Denote significant different at $P<0.05$ compared with the control. Means followed by same alphabet in a column do not differ significantly by Tukeys test $\mathrm{P}<0.05$. 
Table 3 Ovicidal activity of $O$. basilicum EO, methyl chavicol and linalool on $M$. domestica eggs

\begin{tabular}{|c|c|c|c|c|c|c|c|}
\hline Test sample & $\begin{array}{l}\text { Concentration } \\
\left(\mathrm{mg} / \mathrm{dm}^{3}\right)\end{array}$ & $\begin{array}{l}48 \mathrm{~h} \% \text { mortality } \\
\pm \mathrm{SE}\end{array}$ & $\begin{array}{l}\mathrm{EC}_{50} \\
\left(\mathrm{mg} / \mathrm{dm}^{3}\right)\end{array}$ & $95 \% \mathrm{CL}$ & $\mathrm{df}$ & Chi-square & $P$ value \\
\hline \multirow{7}{*}{$\begin{array}{l}\text { O. basilicum } \\
\text { EO }\end{array}$} & 45.59 & $100 \pm 0$ & & & & & \\
\hline & 30 & $86 \pm 2.91$ & 9.74 & $7.36-12.75$ & 5 & 10.79 & 0.058 \\
\hline & 22.79 & $68 \pm 2.54$ & & & & & \\
\hline & 11.4 & $51 \pm 4.30$ & & & & & \\
\hline & 5.7 & $28 \pm 2.54$ & & & & & \\
\hline & 0.3 & $16 \pm 1.87$ & & & & & \\
\hline & 0.15 & $6 \pm 1.0$ & & & & & \\
\hline \multirow[t]{7}{*}{ Methyl chavicol } & 45.59 & $99 \pm 0.00$ & 10.67 & $8.70-13.01$ & 5 & 8.83 & 0.116 \\
\hline & 30 & $85 \pm 1.58$ & & & & & \\
\hline & 22.79 & $72 \pm 2.54$ & & & & & \\
\hline & 11.39 & $48 \pm 2.54$ & & & & & \\
\hline & 5.6 & $29 \pm 2.91$ & & & & & \\
\hline & 2.8 & $8 \pm 1.22$ & & & & & \\
\hline & 1.5 & $3 \pm 1.22$ & & & & & \\
\hline \multirow[t]{8}{*}{ Linalool } & 79.33 & $100 \pm 0.00$ & 13.57 & $11.39-15.93$ & 6 & 10.58 & 0.102 \\
\hline & 63.47 & $94 \pm 2.44$ & & & & & \\
\hline & 39.66 & $84 \pm 4.30$ & & & & & \\
\hline & 23.8 & $74 \pm 1.87$ & & & & & \\
\hline & 15.86 & $63 \pm 2.54$ & & & & & \\
\hline & 11.9 & $44 \pm 2.91$ & & & & & \\
\hline & 7.93 & $20 \pm 2.23$ & & & & & \\
\hline & 3.96 & $12 \pm 2.54$ & & & & & \\
\hline \multirow[t]{7}{*}{ DDVP } & 1.2 & $95 \pm 2.73$ & 0.15 & $0.13-0.18$ & 5 & 1.43 & 0.92 \\
\hline & 0.64 & $84 \pm 2.44$ & & & & & \\
\hline & 0.32 & $69 \pm 4.30$ & & & & & \\
\hline & 0.16 & $51 \pm 2.91$ & & & & & \\
\hline & 0.08 & $28 \pm 2.54$ & & & & & \\
\hline & 0.04 & $15 \pm 1.58$ & & & & & \\
\hline & 0.02 & $8 \pm 1.22$ & & & & & \\
\hline
\end{tabular}

Each value represents the mean of five replicates, and each set-up had 20 individuals $(n=100)$.

95\% $\mathrm{CL}=$ confidence interval at $95 \%$ confidence level

brevicomis and mountain pine beetle, D.ponderosae by 60 and 68\%, respectively (Hobson Kenneth 1995). Screening of the odorants for antennal response using EAG provides a lead to select the compounds for behavioural assays (Cosse et al. 1995; Zito et al. 2013; Ruschioni et al. 2015) as the EAG active compounds in the essential oils could elicit attractive or repulsive behavioural response (Meza et al. 2020)

Compounds that result in a physiological response in antennae need not be behaviorally active, hence an olfactory assay must be performed to establish the behavioral response
Table 4 Acute toxicity of O. basilicum $\mathrm{EO}$, methyl chavicol and linalool on $M$. domestica Topical application

\begin{tabular}{llllllll}
\hline Test sample & Stage & Period (Hours) & $\mathrm{LD}_{50} *$ & $95 \% \mathrm{CL}$ & $\mathrm{df}$ & $\begin{array}{l}\text { Chi- } \\
\text { square }\end{array}$ & $P$ value \\
\hline O.basilicum EO & Adult & 24 & 10.01 & $9.19-10.94$ & 6 & 11.83 & 0.066 \\
Methyl chavicol & Adult & 24 & 13.62 & $10.76-16.78$ & 4 & 9.19 & 0.05 \\
Linalool & Adult & 24 & 43.12 & $23.80-64.39$ & 2 & 5.93 & 0.05 \\
Imidacloprid & Adult & 24 & 1.41 & $1.19-1.68$ & 5 & 2.8 & 0.718 \\
\hline
\end{tabular}

*( $\mu$ g/adult $)$ 
Table 5 Activities of carboxylesterase and glutathione S-transferase in M. domestica adult

\begin{tabular}{lllll}
\hline Treatment & $\begin{array}{l}\text { GST } \\
\mathrm{a}, \mathrm{b}\end{array}$ & ER & $\begin{array}{l}\text { Car E } \\
\mathrm{a}, \mathrm{b}\end{array}$ & ER \\
\hline Control & $15.58 \pm 0.49^{\mathrm{e}}$ & & $1.35 \pm 0.04^{\mathrm{e}}$ & \\
O. basilicum EO LD $_{50}$ & $71.83 \pm 1.92^{\mathrm{a}}$ & 4.61 & $2.21 \pm 0.00^{\mathrm{b}}$ & 1.63 \\
Methyl chavicol LD 50 & $48.16 \pm 2.76^{\mathrm{b}}$ & 3.09 & $1.53 \pm 0.03^{\mathrm{de}}$ & 1.13 \\
Linalool LD $_{50}$ & $13.86 \pm 0.37^{\mathrm{e}}$ & 0.88 & $2.84 \pm 0.07^{\mathrm{a}}$ & 2.10 \\
\hline
\end{tabular}

aMeans within a column followed by the same letter is not significantly different (One-way ANOVA)

bUnit of enzymes: GST - Glutathione S-transferase and Car E Carboxylesterase $=\mathrm{n}$ moles $/ \mathrm{min} / \mathrm{mg}$ protein $/ \mathrm{min}$

The enzyme activities were expressed as enzyme ratio (ER, mean activity of enzyme in different treatments/mean activity of enzyme in control group)

(Ravindran et al. 2019). In the Y-tube olfactory assay, the adults of $M$. domestica preferred the control arm containing a food source alone over the arm having food source laced with sweet basil EO and methyl chavicol. This aversive response of $M$. domestica adults to EO and methyl chavicol may be due to its ability to perceive the odorants in antennae. The peripheral response of antennal neurons to EO and methyl chavicol in EAG provides a physiological basis for the aversive olfactory mediated behaviour in Y-tube assay. The essential oils of Ocimum gratissimum, Thymus serpyllum, Myristica fragrans and Curcuma amada caused $100 \%$ repellence to housefly for a duration of 5 h. (Singh and Singh 1991). Vanillin, p-menthane3,8-diol (PMD) and neem oil at 5\% caused significant repellence to $M$. domestica adults (Khater and Geden 2019). Combinations of EOs, viz., Chrysopogon zizanioides, Cinnamomum zeylanicum, and Lavandula angustifolia along with sunflower oil caused repellence to the blow fly Lucilia sericata (Khater and Geden 2019). Methyl chavicol, a constituent in Tagetes filifolia and $O$. selloi, was also found to be repellent to Aedes aegypti (Diptera) (Gleiser et al. 2011) and Anopheles braziliensis (Diptera) (Padilha de Paula et al. 2003). Sadeh et al. (2019) reported that rosemary variety 11 having 0.6-0.9 \% methyl chavicol elicited repellency to whitefly, Bemesia tabaci. Hobson Kenneth (1995) further reported that methyl chavicol reduced the aggregation of Dendroctonus beetles. Repellents prevent the orientation/alighting of houseflies on treated surfaces and can therefore reduce the spread of diseases in locations where the housefly is high (Haselton et al. 2015). Identifying repellents for the house fly is of paramount importance because of its negative impacts on agriculture and human health (Malik et al. 2007). Assessing the repellents of bioactive compounds to flies in small space using olfactometers is difficult to arrive at a conclusion. The behavioural response involving cage studies will facilitate to confirm the response in Y-tube olfactory assays (Khater and Geden 2019).
Cages having oviposition substrate treated with O. basilicum EO and its components methyl chavicol and linalool at $0.25 \%$ showed highest ovipositional repellence against $M$. domestica with values ranging from 79 to $89 \%$ and an OAI of -0.65 to -0.67 . Essential oil of $O$. gratissimum at $2 \%$ also caused $100 \%$ repellent activity against M. domestica (Singh and Singh 1991). The repellence of essential oil against $M$. domestica has impact on the population build up (Maganga et al. 1996). The toxic effects of O. basilicum, EO and its constituent's methyl chavicol and linalool to larval, pupal and adult stages of $M$. domestica has been documented (Pavela 2008b; Tarelli et al. 2009; Scalerandi et al. 2018). Identifying the essential oil with ovicidal activity can contain the pest buildup (Hong et al. 2018). Eggs of $M$. domestica are easier to target than motile larval and adult stages. $O$. basilicum EO had 5.8-fold higher ovicidal activity on $M$. domestica eggs than its constituent's linalool or methyl chavicol. Eggs of mosquito vectors, Aedes aegypti, Anopheles dirus and Culex quinquefasciatus exposed to O. basilicum oil had extremely low hatch rates $\left(\mathrm{EC}_{50}<\right.$ $1.9 \%$ ) (Siriporn and Mayura 2012) O. basilicum oil at 1.0 $\mathrm{ml} / 38.5 \mathrm{ml}$ of air caused $100 \%$ mortality of Callosobruchus chinensis (L.) 3 days after the exposure period (Abd El-Salam 2010), and linalool also showed ovicidal activity against the eggs of insecticide resistant lice BR-HL females (Yang et al. 2009). Transgenic Nicotiana tabacum producing higher levels of linalool were not preferred for oviposition by Helicoverpa armigera as linalool was reported to cause repellence (McCallum et al. 2011).

We observed that topical application of $O$. basilicum EO was more toxic than methyl chavicol and linalool to adult stages of $M$. domestica. Increased toxicity in EO may be due to the combined effect of the compounds in natural oil as reported by Cheng et al. (2009). In contrast, methyl chavicol (11.01 ppm) and linalool (35.17 ppm) in isolation had higher larvicidal activity than Clausena anisate $\mathrm{EO}$ as a whole $\left(\mathrm{LC}_{50}\right.$ 119.59 ppm) (Govindarajan 2010). Chrysopogon zizanioides, Cinnamomum zeylanicum, and Lavandula angustifolia $(0.6 \%)$ caused $100 \%$ mortality of adult $M$. domestica by topical and fumigant exposure (Khater and Geden 2019). The lipophilicity coupled with low molecular weight of EOs enable them to show various modes of action on insects (Pavela and Benelli 2016). The structure and functional group of terpenoids facilitates their entry into the insect cuticle and attach to the target site to bring in desirable bioaction (Rice and Coats 1994).

Resistance of insects to xenobiotics and phytochemicals is due to metabolic detoxification mediated by the action of enzymes like, glutathione $S$-transferase (GST) and esterase (Castaneda et al. 2010; Waliwitiya et al. 2012). GST is involved in the metabolism of endogenous compounds and acts by conjugation to make them water soluble and less toxic ( $\mathrm{Yu}$ 2004). Esterases act by binding, sequestering, and detoxifying toxic chemicals (Hegeto et al. 2015) 
Our investigations reveal that GST and Car E activity in adult stage of $M$. domestica increased on exposure to $O$. basilicum EO and methyl chavicol and linalool. $M$. domestica adults exposed to EO at LD 50 values induced a higher level of GST as compared with control and constituents. Treating with $\mathrm{LD}_{50}$ doses of linalool caused significant increase in Car E levels in adults. This agrees with earlier studies that $C$. pipiens larvae exposed $O$. basilicum $\mathrm{EO}$ at $\mathrm{LC}_{50}$ values stimulated GST activity. The increase in degrading enzymes may be due to increase in active compounds in the insect body (Zibaee and Bandani 2010). Previous reports state that plantderived products having a mixture of compounds that including triterpenoids and phenols inhibit the activity of GST and Car E (Tak et al. 2017; Yang et al. 2018). An increase in the degrading enzymes Car E and GST on exposure of insects to natural products have been reported earlier (Kumrungsee et al. 2014). Larvae of mosquitoes, C.quinquefasciatus and A. stephensi exposed to Lantana camera root and Anacardium occidentale exhibited a rise in GST activity. This scenario of rise in enzymes does not limit to insecticide resistance alone, and this could be due to degrading enzymes generated by reactive oxygen species (ROS) (Vontas et al. 2001). Induction of detoxifying enzymes due to exposure to EO may be due to synergy caused by the constituents in EO (Miresmailli et al. 2006; Isman et al. 2008; Jiang et al. 2009; Senthil-Nathan 2013). Increase in degrading enzyme levels is clear indication that EO and its constituents possess cidal effect in M. domestica and the fall out of which is the possibilities of resistance development, which needs further investigation.

The work in this study has demonstrated the bioactive potential of $O$. basilicum EO and its constituents, methyl chavicol and linalool in toxicity to eggs and adult stage. The electrophysiological and behavioral response of adult female flies to EO and its constituents by inducing repellence and ovipositional deterrence in adults can be used to deter fly populations from infesting human settlements and animal sheds. O. basilicum EO as whole induces a higher ovicidal, adulticidal and repellency to flies, and these traits make it fit for integrated pest management (IPM) of $M$. domestica. Further studies are needed to develop a formulation of $O$. basilicum EO for sustained spatiotemporal release rates as there is a market demand for plant-derived parts for managing the pests like M. domestica.

Acknowledgements Support provided by ICAR - NBAIR and facilities provided by Chairperson, DOS in Zoology, University of Mysore is acknowledged. Suggestions provided by Dr. Shannon Olsson, NCBS TIFR in fine tuning the manuscript, are acknowledged.
Authors' contribution Rajendran Senthoorraja: Investigation, Data generation. Kesavan Subaharan: Conceptualization, Writing - Original Draft, Data Curation. Sowmya Manjunath: Investigation on biochemical aspects. Muthu Gounder Mohan: Resources. Vppalayam Shanmugam Pragadheesh: Investigation, Validation. Nandagopal Bakthavatsalam: Writing - Review \& Editing. Sekarappa Basavarajappa: Writing - Review \& Editing. Sengottayan SenthilNathan: Writing - Original Draft and editing.

All authors read and approved the final manuscript.

Funding The work was supported by ICAR - NBAIR as institutional project. The first author was supported as JRF by Department of Biotechnology, Govt. of India vide: BT/PR10174/NNT/28/716/2013. Facilities provided by Chairperson, DOS in Zoology, University of Mysore, is acknowledged.

Data availability Data is available by request to the corresponding author.

\section{Declarations}

Ethics approval and consent to participate Not applicable.

Consent for publication Not applicable.

Competing interest Authors declare no conflict of interest.

\section{References}

Abd El-Salam AME (2010) Toxic and deterrent effects of two volatile oils against cowpea weevil, Callosobruchus chinensis (Coleoptera: Bruchidae). Arch Phytopathol Plant Protect 43(16):1596-1607. https://doi.org/10.1080/03235400802677735

Alam M, Shah RM, Shad SA, Binyameen M (2020) Fitness cost, realized heritability and stability of resistance to spiromesifen in house fly, Musca domestica L. (Diptera: Muscidae). Pestic Biochem Physiol 168:104648. https://doi.org/10.1016/j.pestbp.2020.104648

Benelli G, Pavela R (2018) Beyond mosquitoes-essential oil toxicity and repellency against bloodsucking insects. Ind Crop Prod 117:382392. https://doi.org/10.1016/j.indcrop.2018.02.072

Benelli G, Pavela R, Giordani C, Casettari L, Curzi G, Cappellacci L, Petrelli R, Maggi F (2018) Acute and sub-lethal toxicity of eight essential oils of commercial interest against the filariasis mosquito Culex quinquefasciatus and the housefly Musca domestica. Ind Crop Prod 112:668-680. https://doi.org/10.1016/j.indcrop.2017. 12.062

Bradford MM (1976) A rapid and sensitive method for the quantitation of microgram quantities of protein utilizing the principle of protein-dye binding. Anal Biochem 72(1-2):248-254. https://doi.org/10.1016/ 0003-2697(76)90527-3

Castaneda LE, Figueroa CC, Nespolo RF (2010) Do insect pests perform better on highly defended plants? costs and benefits of induced detoxification defenses in the aphid Sitobion avenae. J Evol Biol 23(11):2474-2483. https://doi.org/10.1111/j.1420-9101.2010. 02112.x

Cheah SX, Tay JW, Chan LK, Jaal Z (2013) Larvicidal, oviposition, and ovicidal effects of Artemisia annua (Asterales: Asteraceae) against Aedes aegypti, Anopheles sinensis, and Culex quinquefasciatus (Diptera: Culicidae). Parasitol Res 112(9):3275-3282. https://doi. org/10.1007/s00436-013-3506-0

Chellappandian M, Vasantha-Srinivasan P, Senthil-Nathan S, Karthi S, Thanigaivel A, Ponsankar A, Kalaivani K, Hunter WB (2018) Botanical essential oils and uses as mosquitocides and repellents 
against dengue. Environ Int 113:214-230. https://doi.org/10.1016/j. envint.2017.12.038

Chellappandian M, Senthil-Nathan S, Vasantha-Srinivasan P, Karthi S, Thanigaivel A, Kalaivani K, Sivanesh H, Stanley-Raja V, Chanthini KM, Shyam-Sundar N (2019) Target and non-target botanical pesticides effect of Trichodesma indicum (Linn) R. Br. and their chemical derivatives against the dengue vector, Aedes aegypti L. Environ Sci Pollut Res 26(16):16303-16315. https://doi.org/10.1007/ s11356-019-04870-3

Cheng SS, Chang HT, Lin CY, Chen PS, Huang CG, Chen WJ, Chang ST (2009) Insecticidal activities of leaf and twig essential oils from Clausena excavata against Aedes aegypti and Aedes albopictus larvae. Pest Manag Sci 65(3):339-343. https://doi.org/10.1002/ps. 1693

Chowdhary K, Kumar A, Sharma S, Pathak R, Jangir M (2018) Ocimum $s p$. source of biorational pesticides. Ind Crop Prod 122:686-701. https://doi.org/10.1016/j.indcrop.2018.05.068

Cosse AA, Todd JL, Millar JG, Martinez LA, Baker TC (1995) Electroantennographic and coupled gas chromatographicelectroantennographic responses of the Mediterranean fruit fly, Ceratitis capitata, to male-produced volatiles and mango odor. J Chem Ecol 21:1823-1836. https://doi.org/10.1007/BF02033679

da Silva Moura EDS, D'Antonino Faroni LR, Fernandes Heleno FF, Aparecida Zinato Rodrigues AAZ, Figueiredo Prates LH, Lopes Ribeiro de Queiroz ME (2020) Optimal extraction of Ocimum basilicum essential oil by association of ultrasound and hydrodistillation and its potential as a biopesticide against a major stored grains pest. Molecules 25(12):2781. https://doi.org/10.3390/ molecules 25122781

Dehghani R, Kassiri H (2020) A brief review on the possible role of houseflies and cockroaches in the mechanical transmission of coronavirus disease 2019 (COVID-19). Arch Clin Infect Dis Online ahead of Print 15(COVID-19):e102863. https://doi.org/10.5812/ archcid. 102863

Delille L (2007) Medicinal Plants in Algeria. BERTI, AIgeria

El Zayyat EA, Soliman MI, Elleboudy NA, Ofaa SE (2015) Musca domestica laboratory susceptibility to three ethnobotanical culinary plants. Environ Sci Pollut Res 22(20):15844-15852. https://doi.org/ 10.1007/s11356-015-4796-9

Fotedar R (2001) Vector potential of houseflies (Musca domestica) in transmission of Vibrio cholerae in India. Acta Trop 78(1):31-34. https://doi.org/10.1016/S0001-706X(00)00162-5

Gallardo A, Picollo MI, Mougabure-Cueto G (2015) Lethal activity of individual and mixed monoterpenoids of geranium essential oil on Musca domestica. Parasitol Res 114(3):1229-1232. https://doi.org/ 10.1007/s00436-015-4315-4

Ghabbari M, Guarino S, Caleca V, Saiano F, Sinacori M, Baser N, Mediouni-Ben Jemaa J, Lo Verde G (2018) Behavior-modifying and insecticidal effects of plant extracts on adults of Ceratitis capitata (Wiedemann) (Diptera Tephritidae). J Pest Sci 91:907917. https://doi.org/10.1007/s10340-018-0952-6

Ghosh A, Zurek L (2015) Fresh steam-flaked corn in Cattle feedlots is an important site for fecal coliform contamination by house flies. J Food Prot 78(3):567-572. https://doi.org/10.4315/0362-028X.JFP$14-429$

Gleiser RM, Bonino MA, Zygadlo JA (2011) Repellence of essential oils of aromatic plants growing in Argentina against Aedes aegypti (Diptera: Culicidae). Parasitol Res 108:69-78. https://doi.org/10. 1007/s00436-010-2042-4

Govindarajan M (2010) Chemical composition and larvicidal activity of leaf essential oil from Clausena anisata (Willd.) Hook. f. ex Benth (Rutaceae) against three mosquito species. Asian Pac J Trop Med 3(11):874-877. https://doi.org/10.1016/s1995-7645(10)60210-6

Habig WH, Pabst MJ, Jakoby WB (1974) Glutathione S-Transferases The first enzymatic step in mercapturic acid formation. J Biol Chem 249(22):7130-7139 http://www.jbc.org/content/249/22/7130
Haselton AT, Acevedo A, Kuruvilla J, Werner E, Kiernan E, Dhar P (2015) Repellency of $\alpha$-pinene against the house fly, Musca domestica. Phytochem 117:469-475. https://doi.org/10.1016/j. phytochem.2015.07.004

Hegeto LA, Ronqui L, Lapenta AS, Albuquerque FA (2015) Identification and functional characterization of esterases in Euschistus heros (Hemiptera, Pentatomidae) and their relationship with thiamethoxam and lambda-cyhalothrin. Genet Mol Res 14(3): 11079-11088. https://doi.org/10.4238/2015.September.22.1

Hobson Kenneth R (1995) Host compounds as semiochemicals for bark beetles. In: Salom Scott M, Hobson Kenneth R (eds) Application of semiochemicals for management of bark beetle infestations: proceedings of an Informal Conference, USDA Forest Service General Technical Report INT-GRT-318, pp 48-51

Hong T, Perumalsamy H, Jang K, Na E, Ahn Y (2018) Ovicidal and larvicidal activity and possible mode of action of phenylpropanoids and ketone identified in Syzygium aromaticum bud against Bradysia procera. Pestic Biochem Physiol 145:29-38. https://doi.org/10. 1016/j.pestbp.2018.01.003

Ikbal C, Pavela R (2019) Essential oils as active ingredients of botanical insecticides against aphids. J Pest Sci 92:971-986. https://doi.org/ 10.1007/s10340-019-01089-6

Isman MB (2006) Botanical Insecticides, deterrents, and repellents in modern agriculture and an increasingly regulated world. Annu Rev Entomol 51(1):45-46. https://doi.org/10.1146/annurev.ento.51. 110104.151146

Isman MB (2017) Bridging the gap: moving botanical insecticides from the laboratory to the farm. Ind Crop Prod 110:10-14. https://doi.org/ 10.1016/j.indcrop.2017.07.012

Isman MB (2020) Botanical insecticides in the twenty-first century-fulfilling their promise? Annu Rev Entomol 65(1):233-249. https:// doi.org/10.1146/annurev-ento-011019-025010

Isman MB, Wilson JA, Bradbury R (2008) Insecticidal activities of commercial rosemary oils (Rosmarinus officinalis) against larvae of Pseudaletia unipuncta and Trichoplusia ni in relation to their chemical compositions. Pharm Biol 46(2):82-87. https://doi.org/10.1080/ 13880200701734661

Jiang Z, Akhtar Y, Bradbury R, Zhang X, Isman MB (2009) Comparative toxicity of essential oils of Litsea pungens and Litsea cubeba and blends of their major constituents against the cabbage looper, Trichoplusia ni. J Agric Food Chem 57(11):4833-4837. https:// doi.org/10.1021/jf900274r

Kaufman PE, Nunez SC, Mann RS, Christopher GJ, Scharf ME (2010) Nicotinoid and pyrethroid insecticide resistance in houseflies (Diptera: Muscidae) collected from Florida dairies. Pest Manag Sci 66(3):290-294. https://doi.org/10.1002/ps. 1872

Khamesipour F, Lankarani KB, Honarvar B, Kwenti TE (2018) A systematic review of human pathogens carried by the housefly (Musca domestica L.). BMC Public Health 18(1):1049. https://doi.org/10. 1186/s12889-018-5934-3

Khan HAA, Akram W, Arshad M, Haffez F (2015) Toxicity and resistance of field collected Musca domestica (Diptera: Muscidae) against insect growth regulator insecticides. Parasitol Res 115(4): 1385-1390. https://doi.org/10.1007/s00436-015-4872-6

Khater HF, Geden CJ (2019) Efficacy and repellency of some essential oils and their blends against larval and adult house flies, Musca domestica L. (Diptera: Muscidae). J Vector Ecol 44(2):256-263. https://doi.org/10.1111/jvec.12357

Koul O, Walia S, Dhaliwal GS (2008) Essential oils as green pesticides: Potential and constraints. Biopestic Int 4:63-84

Kramer WL, Mulla S (1979) Oviposition attractants and repellents of mosquitoes: Oviposition responses of Culex mosquitoes to organic infusions. Environ Entomol 8(6):1111-1117. https://doi.org/10. 1093/ee/8.6.1111

Kumar P, Mishra S, Malik A, Satya S (2012) Insecticidal evaluation of essential oils of Citrus sinensis L. (Myrtales: Myrtaceae) against 
housefly, Musca domestica L. (Diptera: Muscidae). Parasitol Res 110(5):1929-1936. https://doi.org/10.1007/s00436-011-2719-3

Kumrungsee N, Pluempanupat W, Koul O, Bullangpoti V (2014) Toxicity of essential oil compounds against diamondback moth, Plutella xylostella, and their impact on detoxification enzyme activities. J Pest Sci 87(4):721-729. https://doi.org/10.1007/s10340-0140602-6

Lawrence BM (1998) A world perspective. Proceedings of the 10th international congress of essential oils, fragrances and flavors, Washington, DC, USA. Amsterdam: Elsevier Science Publisher BV, USA, p 161

Li X, Schuler MA, Berenbaum MR (2007) Molecular mechanisms of metabolic resistance to synthetic and natural xenobiotics. Annu Rev Entomol 52(1):231-253. https://doi.org/10.1146/annurev.ento. 51.110104.151104

Macovei L, Miles B, Zureki L (2008) Potential of houseflies to contaminate ready-to-eat food with antibiotic-resistant enterococci. J Food Prot 71(2):435-439. https://doi.org/10.4315/0362-028X-71.2.435

Maganga ME, Gries G, Gries R (1996) Repellency of various oils and pine oil constituents to house flies (Diptera: Muscidae). Environ Entomol 25(5):1182-1187. https://doi.org/10.1093/ee/25.5.1182

Malik A, Singh N, Satya S (2007) House fly (Musca domestica): A review of control strategies for a challenging pest. J Environ Sci Health B 42(4):453-469. https://doi.org/10.1080/ 03601230701316481

McCallum EJ, Cunningham JP, Lucker J, Zalucki MP, De Voss JJ, Botella JR (2011) Increased plant volatile production affects oviposition, but not larval development, in the moth Helicoverpa armigera. J Exp Biol 214:3672-3677. https://doi.org/10.1242/jeb. 059923

Meerberg BG, Vermeer HM, Kijlstra A (2007) Controlling of pathogen transmission by flies on organic pig farms - A Review. Outlook Agric 36(3):193-197. https://doi.org/10.5367/ 000000007781891432

Meza FC, Roberts JM, Sobhy IS, Okumu FO, Tripet F, Bruce TJA (2020) Behavioural and electrophysiological responses of female Anopheles gambiae mosquitoes to volatiles from a mango bait. $\mathrm{J}$ Chem Ecol 46:387-396. https://doi.org/10.1007/s10886-02001172-8

Miresmailli S, Bradbury R, Isman MB (2006) Comparative toxicity of Rosmarinus officinalis L. essential oil and blends of its major constituents against Tetranychus urticae Koch (Acari: Tetranychidae) on two different host plants. Pest Manag Sci 62(4):366-371. https:// doi.org/10.1002/ps.1157

Moon RD (2019) Muscid flies (Muscidae). In: Gary Mullen R, Lance Durden A (eds) Medical and veterinary entomology. Academic Press, London, pp 345-368

Ogendo JO, Kostyukovsky M, Ravid U, Matasyoh JC, Deng AL, Omolo EO, Kariuki ST, Shaaya E (2008) Bioactivity of Ocimum gratissimum L. Oil and two of its constituents against five insect pests attacking stored food products. J Stored Prod Res 44(4):328 334. https://doi.org/10.1016/j.jspr.2008.02.009

Padilha de Paula J, Gomes-Carneiro MR, Paumgartten FJ (2003) Chemical composition, toxicity and mosquito repellency of Ocimum selloi oil. J Ethnopharmacol 88(2-3):253-260. https://doi. org/10.1016/s0378-8741(03)00233-2

Palacios SM, Bertoni A, Rossi Y, Santander R, Urzua A (2009) Insecticidal activity of essential oils from native medicinal plants of Central Argentina against the housefly, Musca domestica (L.). Parasitol Res 106(1):207-212. https://doi.org/10.1007/s00436-009$1651-2$

Pandiyan GN, Mathew N, Munusamy S (2019) Larvicidal activity of selected essential oil in synergized combinations against Aedes aegypti. Ecotoxicol Environ Saf 174:549-556. https://doi.org/10. 1016/j.ecoenv.2019.03.019
Pavela R (2008a) Acute and synergistic effects of some monoterpenoid essential oil compounds on the House Fly (Musca domestica L.). J Essent Oil Bear Plants 11(5):451-459. https://doi.org/10.1080/ 0972060X.2008.10643653

Pavela R (2008b) Insecticidal properties of several essential oils on the house Fly (Musca domestica L.). Phytother Res 22(2):274-278. https://doi.org/10.1002/ptr.2300

Pavela R (2011) Insecticidal properties of phenols on Culex quinquefasciatus Say and Musca domestica L. Parasitol Res 109(6):1547-1553. https://doi.org/10.1007/s00436-011-2395-3

Pavela R, Benelli G (2016) Essential oils as eco-friendly biopesticides? Challenges and constraints. Trends Plant Sci 21(12):1000-1007. https://doi.org/10.1016/j.tplants.2016.10.005

Pavela R, Maggi F, Iannarelli R, Benelli G (2019) Plant extracts for developing mosquito larvicides: From laboratory to the field, with insights on the modes of action. Acta Trop 193:236-271. https://doi. org/10.1016/j.actatropica.2019.01.019

Poorjavad N, Goldansaz SH, Dadpour H, Khajehali J (2014) Effect of Ferula assafoetida essential oil on some biological and behavioral traits of Trichogramma embryophagum and T. evanescens. Biol Control 59:403-413. https://doi.org/10.1007/s10526-014-9583-x

Radulovic NS, Blagojevic PD, Miltojevic AB (2013) $\alpha$-Linalool marker compound of forged/synthetic sweet basil (Ocimum basilicum L.) essential oils. J Sci Food Agric 93(13):3292-3303. https://doi.org/ $10.1002 /$ jsfa. 6175

Ravindran P, Subaharan K, Vibina V, Chandran KP, Prathibha PS, Sujithra M (2019) Essential oil in management of coconut rhinoceros beetle Oryctes rhinoceros L. Indian J Entomol 81(3):603-608. https://doi.org/10.5958/0974-8172.2019.00136.6

Rice PJ, Coats JR (1994) Insecticidal properties of several monoterpenoid to the housefly (Diptera: Muscidae), red flour beetle (Coleoptera: Tenebrionidae), and Southern Corn rootworn (Coleoptera: Chrysomelidae). J Econ Entomol 87(5):1172-1179. https://doi.org/ 10.1093/jee/87.5.1172

Ruschioni S, Riolo P, Verdolini E, Peri E, Guarino S, Colazza S, Romani R, Isidoro N (2015) Fine Structure of Antennal Sensilla of Paysandisia archon and Electrophysiological Responses to Volatile Compounds Associated with Host Palms. PLoS One 10(4):e0124607. https://doi.org/10.1371/journal.pone.0124607

Sadeh D, Nitzan N, Shachter A, Ghanim M, Dudai N (2019) RosemaryWhitefly Interaction: A continuum of repellency and volatile combinations. J Econ Entomol 112(2):616-624. https://doi.org/10.1093/ jee/toy 375

Saeed R, Abbas N, Razaq M, Mahmood Z, Naveed M, Ur Rehman HM (2018) Field evolved resistance to pyrethroids, neonicotinoids and biopesticides in Dysdercus koenigii (Hemiptera: Pyrrhocoridae) from Punjab, Pakistan. Chemosphere 213:149-155. https://doi.org/ 10.1016/j.chemosphere.2018.09.042

Salamatian I, Moshaverinia A, Razmyar J, Ghaemi M (2020) In vitro acquisition and retention of low-pathogenic avian influenza H9N2 by Musca domestica (Diptera: Muscidae). J Med Entomol 57(2): 563-567. https://doi.org/10.1093/jme/tjz175

Sasaki T, Kobayashi M, Agui N (2000) Epidemiological potential of excretion and regurgitation by Musca domestica (Diptera: Muscidae) in the dissemination of Escherichia coli O157: H7 to Food. J Med Entomol 37(6):945-949. https://doi.org/10.1603/ 0022-2585-37.6.945

Scalerandi E, Flores GA, Palacio M, Defago MT, Carpinella MC, Valladares G, Bertoni A, Palacios SM (2018) Understanding Synergistic Toxicity of Terpenes as Insecticides: Contribution of Metabolic Detoxification in Musca domestica L. Front Plant Sci 9: 1579. https://doi.org/10.3389/fpls.2018.01579

Scott JG (2017) Evolution of resistance to pyrethroid insecticides in Musca domestica L. Pest Manag Sci 73(4):716-722. https://doi. org/10.1002/ps.4328 
Senthil-Nathan S (2013) Physiological and biochemical effect of neem and other Meliaceae plants secondary metabolites against Lepidopteran insects. Front Physiol 4:359. https://doi.org/10.3389/ fphys.2013.00359

Senthil-Nathan S (2020) A review of resistance mechanisms of synthetic insecticides and botanicals, phytochemicals, and essential oils as alternative larvicidal agents against mosquitoes. Front Physiol 10: 1591. https://doi.org/10.3389/fphys.2019.01591

Shi J, Zhang L, Mi J, Gao X (2020) Role transformation of fecundity and viability: The leading cause of fitness costs associated with betacypermethrin resistance in Musca domestica. PLoS One 15(1): e0228268. https://doi.org/10.1371/journal.pone.0228268

Simon JE, Morales MR, Phippen WB, Vieira RF, Hao Z (1999) Basil: A source of aroma compounds and a popular culinary and ornamental herb. In: Janick J (ed) Perspectives on New crops and new uses. Alexandria: ASHS Press, VA, pp 499-505

Singh D, Singh AK (1991) Repellent and insecticidal properties of essential oils against housefly, Musca domestica L. Int J Trop Insect Sci 12(04):487-491. https://doi.org/10.1017/s1742758400011401

Sinthusiri J, Soonwera M (2014) Oviposition deterrent and ovicidal activities of seven herbal essential oils against female adults of housefly, Musca domestica L. Parasitol Res 113(8):3015-3022. https:// doi.org/10.1007/s00436-014-3964-z

Siriporn P, Mayura S (2012) The effects of herbal essential oils on the oviposition deterrent and ovicidal activities of Aedes aegypti (Linn.), Anopheles dirus (Peyton and Harrison) and Culex quinquefasciatus (Say). Trop Biomed 29(1):138-150

Sonmezdag AS, Amanpour A, Kelebek H, Selli S (2018) The most aroma-active compounds in shade-dried aerial parts of basil obtained from Iran and Turkey. Ind Crop Prod 124:692-698. https://doi. org/10.1016/j.indcrop.2018.08.053

Subaharan K, Senthoorraja R, Manjunath S, Thimmegowda GG, Pragadheesh VS, Bakthavatsalam N, Mohan MG, Senthil-Nathan S, David KJ, Basavarajappa S, Ballal C (2021) Toxicity, behavioural and biochemical effect of Piper betle L. essential oil and its constituents against housefly, Musca domestica L. Pestic Biochem Physiol 174:104804. https://doi.org/10.1016/j.pestbp.2021.104804

Tak JH, Jovel E, Isman MB (2017) Effects of rosemary, thyme and lemongrass oils and their major constituents on detoxifying enzyme activity and insecticidal activity in Trichoplusia ni. Pestic Biochem Physiol 140:9-16. https://doi.org/10.1016/j.pestbp.2017.01.012

Tarelli G, Zerba EN, Alzogaray RA (2009) Toxicity to vapor exposure and topical application of essential oils and monoterpenes on Musca domestica (Diptera: Muscidae). J Econ Entomol 102(3):1383-1388. https://doi.org/10.1603/029.102.0367

Telci I, Bayram E, Y1lmaz G, Avc1 B (2006) Variability in essential oil composition of Turkish basils (Ocimum basilicum L.). Biochem Syst Ecol 34(6):489-497. https://doi.org/10.1016/j.bse.2006.01.009

Tian Y (2017) Toxicity and repellency of essential oils to the house fly (Musca domestica L.). Master of Science Thesis, Auburn University, Alabama

Varga F, Carovic-Stanko K, Ristic M, Grdisa M, Liber Z, Satovic Z (2017) Morphological and biochemical intraspecific characterization of Ocimum basilicum L. Ind Crop Prod 109:611-618. https:// doi.org/10.1016/j.indcrop.2017.09.018

Vasantha-Srinivasan P, Thanigaivel A, Edwin ES, Ponsankar A, SenthilNathan S, Selin-Rani S, Kalaivani K, Hunter WB, Duraipandiyan V, Al-Dhabi NA (2018) Toxicological effects of chemical constituents from Piper against the environmental burden Aedes aegypti Liston and their impact on non-target toxicity evaluation against biomonitoring aquatic insects. Environ Sci Pollut Res Int 25(11): 10434-10446. https://doi.org/10.1007/s11356-017-9714-x

Venugopal V, Subaharan K (2019) Electrophysiological and behavioral response of red palm weevil, Rhynchophorus ferrugineus (Olivier) (Coleoptera: Dryophthoridae) to fermented coconut sap neera. J Plant Crop 47(2):82-89. https://doi.org/10.25081/jpc.2019.v47.i2. 5767

Vontas JG, Small GJ, Hemingway J (2001) Glutathione S-transferases as antioxidant defence agents confer pyrethroid resistance in Nilaparvata lugens. Biochem J 357(1):65-72. https://doi.org/10. 1042/bj3570065

Waliwitiya R, Nicholson RA, Kennedy CJ, Lowenberger CA (2012) The synergistic effects of insecticidal essential oils and piperonylbutoxide on biotransformational enzyme activities in Aedes aegypti (Diptera: Culicidae). J Med Entomol 49(3):614 623. https://doi.org/10.1603/ME10272

Wanaratana S, Amonsin A, Chaisingh A, Panyim S, Sasipreeyajan J, Pakpinyo S (2013) Experimental assessment of houseflies as vectors in avian influenza subtype $\mathrm{H} 5 \mathrm{~N} 1$ transmission in chickens. Avian Dis 57(2):266-272. https://doi.org/10.1637/10347-090412-Reg.1

Wang D, Hu B, Hu C, Zhu F, Liu X, Zhang J, Wang B, Xiang H, Cheng Z, Xiong Y, Zhao Y, Li Y, Wang X, Peng Z (2020) Clinical characteristics of 138 hospitalized patients with 2019 novel coronavirusinfected pneumonia in Wuhan, China. JAMA 323(11):1061-1069. https://doi.org/10.1001/jama.2020.1585

White PR, Hobson KR (1993) Stereospecific antennal response by the red turpentine beetle, Dendroctonus valens to chiral monoterpenes from ponderosa pine resin. J Chem Ecol 19(10):2193-2202. https://doi. org/10.1007/BF00979657

Yang YC, Lee SH, Clark JM, Ahn YJ (2009) Ovicidal and adulticidal activities of Origanum majorana essential oil constituents against insecticide-susceptible and pyrethroid/malathion-resistant Pediculus humanus capitis (Anoplura: Pediculidae). J Agric Food Chem 57(6): 2282-2287. https://doi.org/10.1021/jf803738z

Yang H, Piao X, Zhang L, Song S, Xu Y (2018) Ginsenosides from the stems and leaves of Panax ginseng show antifeedant activity against Plutella xylostella (Linnaeus). Ind Crop Prod 124:412-417. https:// doi.org/10.1016/j.indcrop.2018.07.054

Yu SJ (2004) Induction of detoxification enzymes by triazine herbicides in the fall armyworm, Spodoptera frugiperda. Pestic Biochem Physiol 80(2):113-122. https://doi.org/10.1016/j.pestbp.2004.06. 005

Zhang L, Gao X, Liang P (2007) Beta-cypermethrin resistance associated with high carboxylesterase activities in a strain of house fly, Musca domestica (Diptera: Muscidae). Pestic Biochem Physiol 89(1):6572. https://doi.org/10.1016/j.pestbp.2007.03.001

Zibaee A, Bandani A (2010) A study on the toxicity of a medicinal plant, Artemisia annua L. (Asteracea) extracts to the sunn pest, Eurygaster integriceps Puton (Hemiptera: Scutelleridae). J Plant Prot Res 50(1): 79-85. https://doi.org/10.2478/v10045-010-0014-4

Zito P, Guarino S, Peri E, Sajeva M, Colazza S (2013) Electrophysiological and behavioural responses of the housefly to "sweet" volatiles of the flowers of Caralluma europaea (Guss.) N.E. Br. Arthropod-Plant Interact 7:485-489. https://doi.org/10.1007/ s11829-013-9270-3

Publisher's note Springer Nature remains neutral with regard to jurisdictional claims in published maps and institutional affiliations. 